\title{
New Method for Screening Cowpea Germ Plasm for Resistance to Cucumber mosaic virus
}

\author{
A. G. Gillaspie, Jr., USDA-ARS, Plant Genetic Resources Conservation Unit, 1109 Experiment St., Griffin, GA \\ 30223-1797
}

\begin{abstract}
Gillaspie, A. G., Jr. 2006. New method for screening cowpea germ plasm for resistance to $\mathrm{Cu}$ cumber mosaic virus. Plant Dis. 90:611-614.

Utilizing the Cucumber mosaic virus (CMV)-resistant cowpea germ plasm line, GC-86L-98, a new method of screening for resistance in the greenhouse followed by field screening was developed. A uniform source of CMV inoculum (freeze-dried infected cowpea tissue) was diluted to provide an infection rate in GC-86L-98 similar to that observed under field conditions. Plants of test lines were mechanically inoculated with this standard inoculum rate and assessed under greenhouse conditions. Lines considered equivalent in infection percentage with GC-86L-98 were then evaluated in field tests. Test line plants were exposed to virus from susceptible cultivar Coronet when plants were at the first or second trifoliolate leaf stage, and then leaf samples were assayed by direct antigen coating-enzyme-linked immunosorbent assay. Lines with infection percentages similar to or lower than the resistant control were considered resistant. A new line (PI 441917) with CMV resistance and several lines with Blackeye cowpea mosaic virus resistance were found. Newly discovered CMV-resistant lines will help to control the serious cowpea stunt disease caused by synergism of the two viruses.
\end{abstract}

Cucumber mosaic virus (CMV) causes some mosaic and distortion of leaves of many lines of cowpea (Vigna unguiculata (L.) Walp. subsp. unguiculata). This virus has the potential for seed transmission as well as aphid transmission $(2,4)$. Blackeye cowpea mosaic virus (BlCMV) causes mild to moderate mosaic symptoms on cowpea. These two viruses interact synergistically in cowpea to cause cowpea stunt disease, which causes significant losses in cowpea and is the most serious disease of cowpea in the United States $(1,11)$. The disease causes leaves to be distorted, stunted, mottled, and blistered (11). Severity of the symptoms is dependent upon the line of cowpea that is infected and the strain of CMV that serves as inoculum (unpublished data).

Several strains of CMV are present in Georgia (7), where much of the regeneration of cowpea germ plasm occurs and cowpea stunt is the major disease problem. Cowpea stunt seems to limit seed production of highly susceptible cowpea lines, and both CMV and BlCMV are seedborne in cowpea. The two viruses pose a problem for distribution of germ plasm. Sources of

Corresponding author: A. G. Gillaspie, Jr.

E-mail: s9gg@ars-grin.gov

Accepted for publication 19 December 2005.

DOI: 10.1094/PD-90-0611

This article is in the public domain and not copyrightable. It may be freely reprinted with customary crediting of the source. The American Phytopathological Society, 2006. resistance to BlCMV are known, but no reliable source of resistance to CMV was identified until line GC-86L-98 was registered $(2,5,6,9,10)$.

McWilliams screened 350 lines of cowpea from the cowpea core collection of the National Plant Germplasm System (NPGS) collection in greenhouse tests and found four lines (PI 163142, 164979, 166146, and 201498) that exhibited CMV resistance (10). He reported four other lines (PI 167024, 194206, 194208, and 307558) with possible BlCMV resistance. The eight lines were not tested by McWilliams any further at that time. The cowpea core collection is a group of lines that have been selected as representative of the genetic diversity among the entire cowpea collection of more than 8,000 accessions. There are representatives in this 720 -accession core collection from all of the countries of origin. Greenhouse testing of lines is currently used with mechanically transmitted viruses such as Sugarcane mosaic virus, Blackeye cowpea mosaic virus, Cowpea aphid-borne mosaic virus, and others as a pretesting to select lines with enough promise of resistance to be tested in the field for susceptibility to insect transmission $(3,12)$. When resistance is really tolerance and not complete immunity, one must regulate the initial prescreen testing so that the inoculum level does not eliminate all lines being tested. With the release of GC-86L-98 (PI 612607), a tool became available to help find a useful inoculum level based upon a comparison with what could be expected with the level of resistance of GC-86L-98. A prescreening and field screening method was devised and is reported here along with several new CMV resistant lines.

\section{MATERIALS AND METHODS}

Inoculum. The CMV strain used in these tests was the severe strain reported in 1998 (7). The virus was maintained on cowpea cv. Early Ramshorn. For the inoculation tests in the greenhouse, a batch of Early Ramshorn plants were freshly inoculated. Leaves were harvested at 2 weeks after inoculation, freeze dried, and stored in an airtight container at $-20^{\circ} \mathrm{C}$. The freeze-dried tissue was required because fresh tissue did not give reproducible responses for the dilution tests.

Preliminary tests were conducted in the greenhouse on GC-86L-98 (resistant) and Coronet (susceptible) cowpea plants in 10$\mathrm{cm}$ pots in Metro-Mix 300 (Scotts-Sierra Horticultural Products Co., Marysville, $\mathrm{OH})$ to determine the correct inoculum level for CMV. Dilutions of macerated dried-leaf tissue were made in $0.025 \mathrm{M}$ potassium phosphate buffer, $\mathrm{pH}$ 7.2. The test plants were dusted with 600 grit Carborundum, and the CMV inoculum was applied to the leaves with a cheesecloth pad. Inoculation was repeated 1 week following the first inoculation to reduce the number of plants that escaped infection. A standard inoculum dilution concentration that produced infection levels on GC-86L98 of 10 to $20 \%$ at third trifoliolate stage, similar to those observed in the field, was developed. All the screening tests were performed with this dilution of the freezedried tissue. The inoculations were performed as above.

Greenhouse screening. A total of 39 cowpea accessions were chosen from the cowpea core collection from lines not used by McWilliams in his 1998 study (10), but including the four lines that he suggested as possibly CMV resistant (PI 163142, 164979, 166146, and 201498) (Table 1). Seed from the accessions were planted as above in four groups $(10,11,10,8)$ along with seed of GC-86L-98 (PI 612607), Coronet, and Early Ramshorn. These last three lines were used in each greenhouse test as controls. The plants were inoculated with $1 \mathrm{~g}$ of dried leaf tissue with $200 \mathrm{ml}$ of buffer when the plants had expanded primary leaves (6 to 7 days postseeding) and again 1 week later. The inoculum level used was the level determined to produce an infection percentage to approximate the 
infection level found in the field in GC86L-98. In the fourth test, a group of plants of the same eight lines as were inoculated with CMV were inoculated with BlCMV (BlCMV inoculum level was $1 \mathrm{~g}$ of dried tissue with $50 \mathrm{ml}$ of buffer). In all four tests, leaf samples were taken from each plant, and these were tested by direct antigen coating-enzyme-linked immunosorbent assay (DAC-ELISA) as described previously $(5,8)$. Absorbance was measured using an Emax Microplate Reader (Molecular Devices Corp., Sunnyvale, CA).

In addition to the individual plant ELISA data above, in test 4 with 10 accessions plus the controls, the plants were sampled in groups of 4 to 5 plants by taking a leaf disk from each plant in the group, extracting from all disks in buffer, assaying these samples by DAC-ELISA, and obtaining the average absorbance readings for each accession. These average ELISA values were recorded as a possible way of estimating susceptibility by comparing virus levels as determined by ELISA.

Field screening. Lines to be included in the field screening tests were selected based on the results of the greenhouse tests as compared to the GC-86L-98 results in that test (Table 2). Test I was the first screening, with seeds planted in the field on 11 June 2002 in a randomized complete block design with four replicates, having $50 \% \mathrm{CMV}$-inoculated and 50\% BlCMVinoculated Coronet plants transplanted at the time the seeds were planted. Four replications of each of 10 test accessions plus Coronet and GC-86L-98 were used for test I. Each single-row plot was $3 \mathrm{~m}$ long with a 3-m row spacing and 3-m alleys. All treatment rows were adjacent to a row of Coronet that had been mechanically inoculated in the greenhouse and checked for visual symptoms of CMV or BlCMV before transplanting. Three weeks after inoculation, the infected plants were hand- transplanted, with 12 to 15 plants per single-row plot, in the field. Healthy plants, 12 to 15 plants per replication, of the test lines were grown in the greenhouse and transplanted on the same day as the infected row plants.

A second screening test, test II, was transplanted in a Griffin field on 29 May, and the final samples were collected on 18 August 2003, with CMV- and BlCMVinfected Coronet plants transplanted at the same time. This test was a randomized complete block design with four replications.

In test III, seeds were planted on 2 June, August 2004. A randomized complete block design was used with three replications of each of 11 test accessions plus Coronet and GC-86L-98. The plot sizes and the spacing were the same as in tests I and II. The Coronet seeds were planted in the greenhouse on the same day as the seeds were planted in the field, and these plants were inoculated and checked for symptoms with both viruses. The infected Coronet plants were hand-transplanted on 28 June.

Infection data for each virus were collected using DAC-ELISA at approximately 1 and 2 months after the test plants were exposed to the infected spreader-row plants. A single leaflet was collected from the test plants from the youngest expanded trifoliolate leaf.

\section{RESULTS AND DISCUSSION}

The method of mechanical inoculation of seedlings in the greenhouse with CMV inoculum at a standard level of 1:200 dilution of freeze-dried, infected leaves followed by screening of the lines with the highest levels of resistance in field spread tests was successful in locating another accession of cowpea with high resistance with moderate CMV resistance (PI 441919). In addition, screening for and the final sample was collected on 31 to CMV (PI 441917) and a second line

BlCMV in the field spread tests identified 11 lines with potential B1CMV resistance: PI 163142, 166146, 583274, and 593117 (test I, data not shown); PI 147071 and 194208 (test II); and PI 441917, 441919, 583271, 583274, and 593117 (test III).

The four lines reported by McWilliams (10) as potential resistant lines for CMV were included in the first greenhouse screening test (Table 1). The level of virus buildup in each line in this test was estimated by DAC-ELISA similar to the approach used by McWilliams in addition to determining the percentage of infected plants. Two (PI 163142 and 166146) of the four lines that he reported had a lower virus buildup and a moderately low infection rate. The other two, PI 164979 and 201498, did not react as he reported. This lack of repeatability and the difficulty of determining virus buildup using average ELISA values led us to use only the percentage of infected plants in determining possible resistant lines in later greenhouse testing. PI 163142 and 166146 were included in field in 2002, but they were overlooked for retesting once the improved method for field spread testing was determined.

The other greenhouse test data are shown in Tables 2 to 4 , and the lines with the most potential for resistance were tested further in the field tests. The BlCMV infection percentages for PI 147071,194208 , and 441917 in the greenhouse (Table 4) correctly selected these lines as resistant as seen in the field test results. This may indicate that resistance to $\mathrm{BlCMV}$ is a different mechanism than that for CMV. This possibility is further supported by the results of the first (2002) field test, in which the high inoculum pressure caused by the plantlets coming up next to infected large susceptible plants did

Table 2. Greenhouse screening for Cucumber mosaic virus (CMV) resistance in cowpea lines determined by direct antigen coating-enzymelinked immunosorbent assay (DAC-ELISA) (April 2002)

Table 1. Greenhouse screening for Cucumber mosaic virus (CMV) resistance in cowpea lines determined by direct antigen coating-enzyme-linked immunosorbent assay (DAC-ELISA) (February 2002)

\begin{tabular}{lccc}
\hline Cowpea line & $\begin{array}{c}\text { CMV-infected } \\
\text { plants/total plants }\end{array}$ & \% Infected & $\begin{array}{c}\text { Mean ELISA } \\
\text { readings } \mathbf{~}^{\mathbf{y}}\end{array}$ \\
\hline Early Ramshorn & $8 / 8$ & 100 & 1.0677 \\
PI 152197 & $14 / 20$ & 70 & 0.3701 \\
PI 163142 & $4 / 18$ & 22 & 0.0885 \\
PI 164979 & $17 / 20$ & 81 & 1.2865 \\
PI 166146 & $6 / 19$ & 32 & 0.1111 \\
PI 183363 & $21 / 25$ & 84 & 1.0454 \\
PI 201498 & $24 / 24$ & 100 & 0.4237 \\
PI 227829 & $18 / 19$ & 95 & 0.3124 \\
PI 352765 & $13 / 17$ & 76 & 0.7152 \\
PI 579849 & $12 / 18$ & 67 & 1.1800 \\
PI 579892 & $3 / 9$ & 33 & 1.3292 \\
Coronet & $19 / 23$ & 83 & 1.0914 \\
GC-86L-98 & $3 / 25$ & 12 & 0.1721 \\
Early Ramshorn & $4 / 7$ & 57 & 1.0105 \\
\hline
\end{tabular}

${ }^{y}$ Samples from four and five plants pooled, read by DAC-ELISA, and averaged for number of plants per accession.

${ }^{\mathrm{z}}$ Cowpea lines reported by McWilliams (10) to have possible CMV resistance.

\begin{tabular}{lcc}
\hline & $\begin{array}{c}\text { CMV-infected } \\
\text { plants/total } \\
\text { plants }\end{array}$ & \% Infected \\
\hline Early Ramshorn & $7 / 10$ & 70 \\
GC-86L-98 & $5 / 11$ & $45^{\mathrm{z}}$ \\
Coronet & $5 / 10$ & 50 \\
PI 583254 & $2 / 10$ & 20 \\
PI 583258 & $7 / 10$ & 70 \\
PI 583271 & $4 / 10$ & 40 \\
PI 583272 & $6 / 10$ & 60 \\
PI 583273 & $6 / 10$ & 60 \\
PI 583274 & $0 / 10$ & 0 \\
PI 593117 & $0 / 10$ & 0 \\
PI 610516 & $5 / 10$ & 50 \\
PI 610517 & $5 / 10$ & 50 \\
PI 610604 & $7 / 10$ & 70 \\
PI 610621 & $7 / 10$ & 70 \\
Early Ramshorn & $7 / 10$ & 70 \\
\hline
\end{tabular}

${ }^{\mathrm{z}}$ The low ELISA readings for this sample mean little virus is present compared with the other lines. 
not reduce the observed resistance to BlCMV infection (data not shown).

In field test I, GC-86L-98 was highly infected with CMV as were the other lines (data not shown). The seeds germinated and produced seedlings in this test next to highly infected Coronet plants. Inoculum pressure with CMV was excessive. As observed in the greenhouse test, the levels of CMV resistance (tolerance) in cowpeas is dependent on inoculum pressure. Therefore, the test plants need to be at the firstor second-trifoliolate leaf stage before the infected plants are introduced. BICMV resistance levels do not change with inoculum pressure in our tests, and lines with resistance hold up with either testing method. The infection percentages in field tests II and III for GC-86L-98 were as expected from earlier experiments (Tables 5 and 6) (5). Test II (Table 5) indicates that PI 441917 is equal to GS-86L-98 in resistance to CMV and BlCMV and PI 441919 is only slightly less resistant. In addition, PI 147071 and 194208 both had good BlCMV resistance.

Test III (Table 6) data confirm the CMV resistance in PI 441917 and 441919. In addition, PI 583245, 583254, and 583271 show CMV resistance, as do PI 147071, 583274, and 593117. PI 147071 was not CMV resistant in test II. PI 147071, 194208, 441917, and 583271 were BlCMV resistant, and PI 441919 and 593117 showed some BlCMV resistance. These results agree with the greenhouse results in some cases. However, some of the greenhouse results do not agree with the results in the field plots in other cases. For example, PI 146618 seemed to be resistant to CMV in the greenhouse, but this line was not resistant in the field test. Therefore, the greenhouse screening is only a quick indication of which lines to test further, and the potential resistant lines must be tested in the field.

The resistance to CMV found in PI 441917 and 441919 was not surprising

Table 3. Greenhouse screening for Cucumber mosaic virus (CMV) resistance in cowpea lines determined by direct antigen coating-enzymelinked immunosorbent assay (May 2002)

\begin{tabular}{lcc}
\hline Cowpea line & $\begin{array}{c}\text { CMV-infected } \\
\text { plants/total } \\
\text { plants }\end{array}$ & \% Infected \\
\hline Early Ramshorn & $10 / 10$ & 100 \\
GC-86L-98 & $2 / 10$ & 20 \\
Coronet & $9 / 10$ & 90 \\
PI 583244 & $2 / 10$ & 20 \\
PI 583245 & $1 / 10$ & 10 \\
PI 583246 & $8 / 10$ & 80 \\
PI 583247 & $9 / 10$ & 90 \\
PI 583248 & $8 / 10$ & 80 \\
PI 583249 & $7 / 10$ & 70 \\
PI 583250 & $6 / 10$ & 60 \\
PI 583251 & $4 / 10$ & 40 \\
PI 583252 & $6 / 10$ & 60 \\
PI 583253 & $5 / 10$ & 50 \\
Early Ramshorn & $6 / 10$ & 60 \\
\hline
\end{tabular}

since these lines originated in Brazil as GC-86L-98, which was selected from PI 441918. These lines vary from PI 441918 and each other based on seed size and

shape and flower appearance. The line, PI 441925, which was also collected in Brazil at the same time, had no resistance to CMV or BlCMV (Tables 1 and 2). Just as

Table 4. Cucumber mosaic virus (CMV) and Blackeye cowpea mosaic virus (BlCMV) resistance greenhouse screening data for cowpea lines determined by direct antigen coating-enzyme-linked immunosorbent assay (September 2002)

\begin{tabular}{lcccc}
\hline Cowpea line & $\begin{array}{c}\text { CMV-infected } \\
\text { plants/total plants }\end{array}$ & \% infected & $\begin{array}{c}\text { BlCMV-infected } \\
\text { plants/total plants }\end{array}$ & \% Infected \\
\hline PI 146618 & $2 / 16$ & 12.5 & $15 / 15$ & 100 \\
PI 147071 & $7 / 15$ & 46.7 & $0 / 15$ & 0 \\
PI 180014 & $6 / 14$ & 42.9 & $14 / 16$ & 87.5 \\
PI 180355 & $11 / 16$ & 68.8 & $13 / 16$ & 81.3 \\
PI 194208 & $2 / 15$ & 13.3 & $0 / 16$ & 0 \\
PI 441917 & $3 / 15$ & 20 & $0 / 15$ & 0 \\
PI 441919 & $3 / 15$ & 20 & $6 / 15$ & 40 \\
PI 441925 & $10 / 16$ & 62.5 & $14 / 16$ & 87.5 \\
GC-86L-98 & $3 / 15$ & 20 & $0 / 15$ & 0 \\
Pinkeye Purplehull & $13 / 15$ & 86.7 & $0 / 14$ & 0 \\
\hline
\end{tabular}

Table 5. Cucumber mosaic virus (CMV) and Blackeye cowpea mosaic virus (BlCMV) resistancescreening data for cowpea lines using infected rows of susceptible cowpeas and direct antigen coatingenzyme-linked immunosorbent assay $(2003)^{\mathrm{y}}$ - test II

\begin{tabular}{llllll}
\hline & \multicolumn{4}{c}{ Infected/total plants (\% infected) } \\
\cline { 2 - 3 } Cowpea line & \multicolumn{3}{c}{ July } & & \multicolumn{2}{c}{ August } \\
\cline { 2 - 3 } \cline { 5 - 6 } PI 146618 & $29 / 69(42)$ & $15 / 69(22)$ & & $48 / 67(72) \mathrm{bc}$ & \multicolumn{1}{c}{ C3/76 (57) d } \\
PI 147071 & $25 / 69(36)$ & $1 / 69(01)$ & & $32 / 60(53) \mathrm{cd}$ & $1 / 60(02) \mathrm{f}$ \\
PI 180014 & $26 / 48(54)$ & $42 / 48(87)$ & & $50 / 50(100) \mathrm{a}$ & $50 / 50(100) \mathrm{a}$ \\
PI 180355 & $29 / 45(64)$ & $26 / 45(58)$ & & $42 / 44(95) \mathrm{a}$ & $39 / 44(89) \mathrm{b}$ \\
PI 194208 & $25 / 74(34)$ & $1 / 74(01)$ & & $35 / 61(57) \mathrm{cd}$ & $1 / 61(02) \mathrm{f}$ \\
PI 441917 & $4 / 81(05)$ & $1 / 81(01)$ & & $26 / 68(38) \mathrm{e}$ & $5 / 68(07) \mathrm{f}$ \\
PI 441919 & $19 / 79(24)$ & $19 / 74(26)$ & & $30 / 73(41) \mathrm{de}$ & $18 / 73(25) \mathrm{e}$ \\
PI 441925 & $38 / 63(60)$ & $19 / 63(30)$ & & $54 / 56(96) \mathrm{ab}$ & $47 / 56(84) \mathrm{c}$ \\
GC-86L-98 & $8 / 78(10)$ & $1 / 78(01)$ & & $21 / 72(29) \mathrm{e}$ & $2 / 72(03) \mathrm{f}$ \\
Pinkeye Purplehull & $45 / 67(67)$ & $36 / 67(54)$ & & $53 / 59(90) \mathrm{a}$ & $50 / 59(85) \mathrm{b}$ \\
\hline
\end{tabular}

${ }^{\mathrm{y}}$ Test plants transplanted from the greenhouse and infected Coronet transplanted into plots between the test plants at the same time into a randomized block design with four replications.

${ }^{\mathrm{z}}$ Means in each column with the same letter(s) are not significantly different at $P \leq 0.05$.

Table 6. Cucumber mosaic virus (CMV) and Blackeye cowpea mosaic virus (BICMV) resistancescreening data for cowpea lines using infected rows of susceptible cowpeas and direct antigen coating-enzyme-linked immunosorbent assay $(2004)^{\mathrm{w}}$ - test III

\begin{tabular}{|c|c|c|c|c|}
\hline \multirow[b]{3}{*}{ Cowpea line } & \multicolumn{4}{|c|}{ Infected/total plants (\% infected) } \\
\hline & \multicolumn{2}{|c|}{ July $^{\mathbf{x}}$} & \multicolumn{2}{|c|}{ August } \\
\hline & CMV & BICMV & CMV $^{\mathbf{y}}$ & BICMV $^{z}$ \\
\hline PI 146618 & $3 / 15(20)$ & $1 / 15(07)$ & $7 / 29$ (24) abc & $11 / 29(38) \mathrm{a}$ \\
\hline PI 147071 & 2/14 (14) & $0 / 14(0)$ & $1 / 21(05)$ bcd & $0 / 21(0) \mathrm{c}$ \\
\hline PI 194208 & $2 / 15(13)$ & $0 / 15(0)$ & $5 / 24(21)$ abcd & $0 / 24(0) c$ \\
\hline PI 441917 & $1 / 15(07)$ & $0 / 15(0)$ & $0 / 16(0) \mathrm{cd}$ & $0 / 16(0) \mathrm{c}$ \\
\hline PI 441919 & $0 / 15(0)$ & $2 / 15(13)$ & $3 / 45(07) \mathrm{cd}$ & $8 / 45$ (18) abc \\
\hline PI 583244 & $0 / 12(0)$ & $0 / 12(0)$ & $11 / 16(69)$ a & $3 / 16$ (19) a \\
\hline PI 583245 & $0 / 15(0)$ & $1 / 15(07)$ & $3 / 28(11) \mathrm{cd}$ & $11 / 28(39) a b$ \\
\hline PI 583254 & $1 / 15(07)$ & $5 / 15(33)$ & $2 / 32(06) \mathrm{cd}$ & $11 / 32(34) a$ \\
\hline PI 583271 & $1 / 15(07)$ & $0 / 15(0)$ & $1 / 31(03) \mathrm{cd}$ & $1 / 31(03) b c$ \\
\hline PI 583274 & $0 / 13(0)$ & $0 / 13(0)$ & $3 / 14$ (21) bcd & $0 / 14(0) \mathrm{c}$ \\
\hline PI 593117 & $2 / 15(13)$ & $0 / 15(0)$ & $2 / 29$ (07) bcd & $2 / 29(07) b c$ \\
\hline GC-86L-98 & $0 / 10(0)$ & $0 / 10(0)$ & $1 / 20(05) \mathrm{d}$ & $0 / 20(0) \mathrm{c}$ \\
\hline Coronet & $3 / 15(20)$ & $0 / 15(0)$ & $8 / 17(47) a b$ & $7 / 17$ (41) abc \\
\hline
\end{tabular}

wTest seeds were planted in the field, and Coronet seeds were planted in the greenhouse on the same day. Infected Coronet plants were transplanted into field plots to serve as inoculum when the test plants were at the first or second trifoliolate leaf stage. Test was planted in a randomized block design with three replications.

${ }^{x}$ July sampling was of leaves from only five plants per rep with GC-86L-98 having one missing rep because of a lost plot.

${ }^{\mathrm{y}}$ Means in each column with the same letter(s) are not significantly different at $P \leq 0.05$.

${ }^{\mathrm{z}}$ Means in this column with the same letter(s) are not significantly different. 
Table 7. Analysis of variance for effects of Cucumber mosaic virus (CMV) and of Blackeye cowpea mosaic virus (B1CMV) on cowpeas in field test in 2003

\begin{tabular}{|c|c|c|c|c|c|c|c|c|}
\hline \multirow[b]{2}{*}{ Source } & \multicolumn{4}{|c|}{ CMV } & \multicolumn{4}{|c|}{ BICMV } \\
\hline & df & Ms & $\boldsymbol{F}$ & $P$ & df & Ms & $\boldsymbol{F}$ & $P$ \\
\hline Rep & 2 & 0.27273000 & 4.18 & 0.0228 & 2 & 0.04928167 & 4.07 & 0.0250 \\
\hline Line & 9 & 3.54448167 & 12.08 & $<0.0001$ & 9 & 0.78385111 & 64.74 & $<0.0001$ \\
\hline Month & 1 & 0.99588167 & 30.54 & $<0.0001$ & 1 & 0.40016667 & 33.05 & $<0.0001$ \\
\hline Line*month & 9 & 0.02965204 & 0.91 & 0.5273 & 9 & 0.05414444 & 4.47 & 0.0005 \\
\hline Residual & 38 & 0.03261061 & $\ldots$ & $\ldots$ & 38 & 0.01210798 & $\ldots$ & $\ldots$ \\
\hline
\end{tabular}

Table 8. Analysis of variance for effects of Cucumber mosaic virus (CMV) and of Blackeye cowpea mosaic virus (BlCMV) on cowpeas in field test in 2004

\begin{tabular}{|c|c|c|c|c|c|c|c|c|}
\hline \multirow[b]{2}{*}{ Source } & \multicolumn{4}{|c|}{ CMV } & \multicolumn{4}{|c|}{ BICMV } \\
\hline & df & Ms & $F$ & $P$ & df & Ms & $F$ & $P$ \\
\hline Rep & 2 & 0.00702782 & 0.29 & 0.7522 & 2 & 0.065115372 & 2.68 & 0.0790 \\
\hline Line & 12 & 0.05345545 & 2.18 & 0.0284 & 12 & 0.07366030 & 3.03 & 0.0031 \\
\hline Month & 1 & 0.10687500 & 4.36 & 0.0422 & 1 & 0.22443289 & 9.22 & 0.0039 \\
\hline Line*month & 12 & 0.05336181 & 2.18 & 0.0287 & 12 & 0.03780698 & 1.55 & 0.1384 \\
\hline Residual & 48 & 0.02453296 & $\ldots$ & $\ldots$ & 48 & 0.02434021 & $\ldots$ & $\ldots$ \\
\hline
\end{tabular}

has been observed with GC-86L-98 (5), the CMV resistance in PI 441917 lessened with time after infection. The early lower percent infection was observed to be important in reducing the effect of cowpea stunt disease on pod production. PI $583245,583254,583271$, and 583274 were all collected in Senegal during the same collecting trip; PI 593117 originated in Botswana; PI 147071 originated from Brazil from a 1943 collecting trip; and PI 194208 is a product of a breeding program in Beltsville, MD (cross of Chinese Red $\times$ Iron). It should be noted that many cowpeas are thought to have originated in Africa, and many good sources of resistance to pathogens have originated at the source of origin of the genus.

When tests II and III were subjected to ANOVA (Tables 7 and 8), the interaction of lines and of the months were significant.

In conclusion, the features of the screening method must include a standard inoculum level for mechanically inoculating CMV into test lines to produce an infection percentage close to that produced in GC-86L-98 in the field. Then, the lines to be tested for "field resistance" should not be exposed to the virus until they are at the first or second leaf stage. Inoculum at too high a titer in the greenhouse tests will not distinguish the resistant lines, just as early exposure to the virus in the field will cause too much infection pressure to select the lines with potential. It should be noted that in the field tests, plants with double infections of CMV and BlCMV did have cowpea stunt symptoms.

\section{ACKNOWLEDGMENTS}

I thank J. H. Chalkley for his help with mechanical inoculations and in the performance of the greenhouse and field tests. I also thank D. L. Pinnow for his help in the serological testing.

\section{LITERATURE CITED}

1. Anderson, E. J., Kline, A. S., Kim, K. S., Goeke, S. C., and Albritton, C. W. 1994. Identification of cowpea stunt disease in south central Arkansas. Farm Res. 43:14-15.

2. Anderson, E. J., Kline, A. S., Morelock, T. E., and McNew, R. W. 1996. Tolerance to Blackeye cowpea mosaic potyvirus not correlated with decreased virus accumulation or protection from cowpea stunt disease. Plant Dis. 80:847-852.

3. Breaux, R. D., and Koike, H. 1978. Problems and progress in breeding sugarcane for mosaic resistance in Louisiana's subtropical environment. Proc. Int. Soc. Sugar Cane Technol. 16:425-432.

4. Francki, R. I. B., Mossop, D. W., and Hatta, T. 1979. Cucumber mosaic virus. CMI/AAB Descriptions of Plant Viruses. No. 213.
5. Gillaspie, A. G., Jr. 2001. Resistance to $\mathrm{Cu}$ cumber mosaic virus in cowpea and implications for control of cowpea stunt disease. Plant Dis. 85:1004-1005.

6. Gillaspie, A. G., Jr. 2002. Registration of GC86L-98 cowpea germplasm resistant to $\mathrm{Cu}-$ cumber mosaic virus and Blackeye cowpea mosaic virus. Crop Sci. 42:1385.

7. Gillaspie, A. G., Jr., Hajimorad, M. R., and Ghabrial, S. A. 1998. Characterization of a severe strain of cucumber mosaic cucumovirus seedborne in cowpea. Plant Dis. 82:419-422.

8. Gillaspie, A. G., Jr., Hopkins, M. S., Pinnow, D. L., and Hampton, R. O. 1995. Seedborne viruses in preintroduction cowpea seed lots and establishment of virus-free accessions. Plant Dis. 79:388-391.

9. Kuhn, C. W., Brantley, B. B., and Sowell, G., Jr. 1966. Southern pea viruses: Identification, symptomatology, and sources of resistance. Ga. Agric. Exp. Stn. Bull. N.S. 157.

10. McWilliams, J. D. 1998. Screening a cowpea germplasm collection for resistance to cowpea stunt-causing viruses. M.S. thesis. University of Arkansas, Fayetteville.

11. Pio-Ribeiro, G., Wyatt, S. D., and Kuhn, C. W. 1978. Cowpea stunt: A disease caused by a synergistic interaction of two viruses. Phytopathology 68:1260-1265.

12. van Boxtel, J., Singh, B. B., Thottappilly, G., and Maule, A. J. 2000. Resistance of cowpea (Vigna unguiculata (L.) Walp.) breeding lines to Blackeye cowpea mosaic and Cowpea aphid-borne potyvirus isolates under experimental conditions. J. Plant Dis. Prot. 107:197204. 